ORIGINAL ARTICLE

\title{
Survival of Desulfotomaculum spores from estuarine sediments after serial autoclaving and high-temperature exposure
}

\author{
Louise A O’Sullivan ${ }^{1}$, Erwan G Roussel ${ }^{1}$, Andrew J Weightman ${ }^{2}$, Gordon Webster ${ }^{1,2}$, \\ Casey RJ Hubert ${ }^{3}$, Emma Bell ${ }^{3}$, Ian Head ${ }^{3}$, Henrik Sass ${ }^{1}$ and R John Parkes ${ }^{1}$ \\ ${ }^{1}$ School of Earth and Ocean Sciences, Cardiff University, Cardiff CF10 3AT, Wales, UK; ${ }^{2}$ Cardiff School \\ of Biosciences, Cardiff University, Cardiff CF10 3AT, Wales, UK and ${ }^{3}$ School of Civil Engineering and \\ Geosciences, Newcastle University, Newcastle upon Tyne NE1 7RU, UK
}

\begin{abstract}
Bacterial spores are widespread in marine sediments, including those of thermophilic, sulphatereducing bacteria, which have a high minimum growth temperature making it unlikely that they grow in situ. These Desulfotomaculum spp. are thought to be from hot environments and are distributed by ocean currents. Their cells and spores upper temperature limit for survival is unknown, as is whether they can survive repeated high-temperature exposure that might occur in hydrothermal systems. This was investigated by incubating estuarine sediments significantly above $\left(40-80^{\circ} \mathrm{C}\right)$ maximum in situ temperatures $\left(\sim 23^{\circ} \mathrm{C}\right)$, and with and without prior triple autoclaving. Sulphate reduction occurred at $40-60^{\circ} \mathrm{C}$ and at $60^{\circ} \mathrm{C}$ was unaffected by autoclaving. Desulfotomaculum sp. C1A60 was isolated and was most closely related to the thermophilic $D$. kuznetsovii ${ }^{\mathrm{T}}(\sim 96 \% 16 \mathrm{~S}$ rRNA gene sequence identity). Cultures of Desulfotomaculum sp. C1A60, D. kuznetsovii'and D. geothermicum B2T survived triple autoclaving while other related Desulfotomaculum spp. did not, although they did survive pasteurisation. Desulfotomaculum sp. C1A60 and D. kuznetsovii cultures also survived more extreme autoclaving (C1A60, $130{ }^{\circ} \mathrm{C}$ for $15 \mathrm{~min}$; $D$. kuznetsovii, $135^{\circ} \mathrm{C}$ for $15 \mathrm{~min}$, maximum of $154^{\circ} \mathrm{C}$ reached) and high-temperature conditions in an oil bath (C1A60, $130^{\circ}$ for $30 \mathrm{~min}$, D. kuznetsovii $140^{\circ} \mathrm{C}$ for $15 \mathrm{~min}$ ). Desulfotomaculum sp. C1A60 with either spores or predominantly vegetative cells demonstrated that surviving triple autoclaving was due to spores. Spores also had very high culturability compared with vegetative cells $(\sim 30 \times$ higher). Combined extreme temperature survival and high culturability of some thermophilic Desulfotomaculum spp. make them very effective colonisers of hot environments, which is consistent with their presence in subsurface geothermal waters and petroleum reservoirs.
\end{abstract}

The ISME Journal (2015) 9, 922-933; doi:10.1038/ismej.2014.190; published online 17 October 2014

\section{Introduction}

Bacterial endospores can withstand multiple environmental stress conditions, such as ionizing radiation, heat, pressure, desiccation, $\mathrm{pH}$ extremes and toxic chemicals and are thus remarkable survival systems (Reineke et al., 2013), able to persist over geological timescales (Cano and Borucki, 1995). Spores are widespread in marine waters and sediments (Muller et al., 2014) and may become relatively more abundant with sediment depth (Fichtel et al., 2008), with numbers possibly equivalent to those of vegetative cells (Lomstein et al., 2012). Spore-forming bacteria have also been isolated from sub-seafloor sediments (for example, Inagaki et al.,

Correspondence: RJ Parkes, School of Earth and Ocean Sciences, Cardiff University, Main Building, Park Place, Cardiff CF10 3AT, Wales, UK.

E-mail: ParkesRJ@Cardiff.ac.uk

Received 27 June 2014; revised 6 August 2014; accepted 16 August 2014; published online 17 October 2014
2003; D'Hondt et al., 2004; Suss et al., 2004) including Gram-positive, spore-forming, thermophilic, sulphate-reducing bacteria (Aullo et al., 2013) who's spores have been shown to have a half-life of $\sim 300$ years in some sediments (de Rezende et al., 2013). It has been suggested that thermophilic spores from warm subsurface petroleum reservoirs and ocean crust ecosystems may be constantly delivered to cold marine sediments via seeps and seawater, and might be able to germinate as the sediment warms during burial (Hubert et al., 2009, 2010). The spores in seawater may also be drawn down through sediments, inoculating them, and then carried along the basalt basement, as part of the ocean aquifer system that feeds hydrothermal vents, and migrate upwards in fractures and faults to inoculate the sediments above (Parkes et al., 2014). In hydrothermal systems spores may initially experience temperatures and pressures that exceed their thermophilic growth limit before reaching conditions suitable for growth. Hence, it would be interesting to know the upper temperature and 
pressure limits that sedimentary spores can survive and how this might vary between different sporeforming bacteria, such as different Desulfotomaculum species. In addition, considering the dynamic nature of hydrothermal systems it would be informative to know whether spores could survive repeated heating cycles with the potential development of superdormant spores (Ghosh et al., 2009). Any enhanced heat stability and ability to withstand multiple high-temperature-pressure cycles would also have implications for sterility in general, and autoclaved controls used in experiments to distinguish between biogenic and thermogenic processes in deep sediments.

The survival temperatures for spore-forming, sulphate-reducing bacteria was addressed during an investigation of the impact of minerals on deep sedimentary biogeochemical processes (Parkes et al., 2011) as previously triple-autoclaved, abiological control sediment slurries (Portishead, Severn Estuary, tidal mud flats, UK) showed active sulphate reduction at $60^{\circ} \mathrm{C}$. The bacteria from these slurries were enriched and isolated and their ability to survive triple autoclaving as both vegetative cells and spores was determined. The maximum autoclave conditions, maximum temperature and range for growth and survival were also determined, and compared with other Desulfotomaculum strains, including $D$. kuznetsovii ${ }^{\mathrm{T}}$ a close relative of the sediment slurry isolate, but from underground $(2800-3250 \mathrm{~m})$ thermal mineral waters (Nazina et al., 1989). To demonstrate that this phenomenon was not restricted to sediments from a single location, we also determined the survival of sulphate-reducing bacteria in sediment slurries from the Tyne and Tamar estuaries, UK, following triple autoclaving.

\section{Materials and methods}

The effect of autoclaving on sulphate reduction in sediment slurries

Severn Estuary tidal mud flat sediments (Portishead, $7-51 \mathrm{~cm}$ depth) were slurried with degassed artificial seawater ( $\mathrm{pH}$ 7.6, 25\% slurry, $2 \mathrm{l}$ total volume, (Wellsbury et al., 1994) and 1\% (v/v) Guaymas Basin hydrothermal sediment added as an additional prokaryotic inoculum. Ground basalt $\left(100 \mathrm{gl}^{-1}\right.$, Parkes et al., 2011) was added, as a mineral addition, and dispensed anaerobically in 10-ml aliquots in crimp vials in an anaerobic cabinet flushed with $\mathrm{N}_{2}$. Replicate vials were autoclaved three times at $121^{\circ} \mathrm{C}$ for $20 \mathrm{~min}$, before being incubated at 40,60 and $80^{\circ} \mathrm{C}$ for up to 100 days. At discrete time intervals (Figure 1) vials were sacrificed for headspace and pore water analysis. At the end of the experiment slurries with active sulphate reduction were subcultured into marine sulphate-reducing bacterial medium with $2 \mathrm{~mm}$ fatty acid mix (see below) at $60{ }^{\circ} \mathrm{C}$. Similar experiments were conducted with Tamar Estuary, UK, sediments. In addition, sediment from the Tyne Estuary, UK (collected at low tide from the black anoxic zone at 20-40 cm depth), were slurried $(2: 1 \mathrm{v} / \mathrm{w}, \mathrm{pH} 7.1$, $20 \mathrm{~mm}$ sulphate) with degassed brackish mineral medium (Widdel and Bak, 1992). Acetate, propionate, butyrate, lactate and glucose were added to a final concentration of $3 \mathrm{~mm}$, and tryptic soy broth to $3 \mathrm{gl}^{-1}$ (source of nutrients, vitamins, minerals and additional substrates). This slurry was then dispensed into 60-ml crimp vials under a constant flow of $\mathrm{N}_{2}$ and sealed with butyl rubber stoppers. Triplicates were autoclaved three times successively as described above before incubation at 50 and $80^{\circ} \mathrm{C}$ for 14 days.

\section{Desulfotomaculum spp. used in this study}

Repeated agar shake tubes (Parkes et al., 2009) were used to isolate pure cultures from a positive subculture of an autoclaved Portishead sediment slurry (C1A60). Two individual colonies were picked and subcultured, but as these showed no differences in appearance and in initial physiological and autoclaving tests, they were considered identical and further experiments were conducted using one of them, Desulfotomaculum sp. C1A60.

A number of additional Desulfotomaculum spp. were investigated for comparison, representing both surface and subsurface species (Table 1). D. kuznetsovii DSM6115 ${ }^{\mathrm{T}}$ (Nazina et al., 1989) and D. thermosapovorans DSM6562 $^{\mathrm{T}}$ (Fardeau et al., 1995) were obtained from the Deutsche Sammlung von Mikroorganismen und Zellkulturen (DSMZ, Braunschweig, Germany). D. acetoxidans DSM771 $1^{\mathrm{T}}$ (Widdel and Pfennig, 1977), D. geothermicum B2T (Sass and Cypionka, 2004) and Desulfotomaculum sp. NC402 (Sass et al., 2003) were from our own culture collection. Growth conditions, temperature range for growth and origin of the strains are given in Table 1.

\section{Growth media and substrates}

For enrichment, isolation and pure-culture experiments two anoxic mineral media were used: (1) an artificial seawater medium containing the following components in $\mathrm{gl}^{-1}$ : $\mathrm{NaCl}$ (24.3), $\mathrm{MgCl}_{2} \cdot 6 \mathrm{H}_{2} \mathrm{O}$ (10), $\mathrm{CaCl}_{2} \cdot 2 \mathrm{H}_{2} \mathrm{O}$ (1.5), KCl (0.66), $\mathrm{Na}_{2} \mathrm{SO}_{4}$ (1.4), $\mathrm{KBr}$ (0.1), $\mathrm{H}_{3} \mathrm{BO}_{3}$ (0.0025), $\mathrm{SrCl}_{2} \cdot 6 \mathrm{H}_{2} \mathrm{O}$ (0.04), $\mathrm{NH}_{4} \mathrm{Cl}$ (0.021), $\mathrm{KH}_{2} \mathrm{PO}_{4}(0.0054)$ and $\mathrm{NaF}(0.003)$, and (2) a freshwater medium containing $\left(\mathrm{gl}^{-1}\right)$ : $\mathrm{NaCl}(0.25)$, $\mathrm{MgCl}_{2} \cdot 6 \mathrm{H}_{2} \mathrm{O}$ (0.25), $\mathrm{CaCl}_{2} \cdot 2 \mathrm{H}_{2} \mathrm{O}$ (0.1), KCl (0.1), $\mathrm{Na}_{2} \mathrm{SO}_{4}$ (1.4), $\mathrm{NH}_{4} \mathrm{Cl}(0.1)$ and $\mathrm{KH}_{2} \mathrm{PO}_{4}$ (0.1). Both media were supplemented with $1 \mathrm{mll}^{-1}$ of traceelement solution SL 10 and $0.2 \mathrm{mll}^{-1}$ of selenite tungstate solution (Widdel and Bak, 1992), and $0.5 \mathrm{ml} \mathrm{l}^{-1}$ of a resazurin solution $\left(0.5 \mathrm{mg} \mathrm{ml}^{-1}\right)$. After autoclaving, the media were cooled under an atmosphere of $\mathrm{N}_{2} / \mathrm{CO}_{2}(80: 20, \mathrm{vol} / \mathrm{vol})$, prior to addition of $10 \mathrm{ml} \mathrm{l}^{-1}$ vitamin solution (Wolin et al., 1963) and 


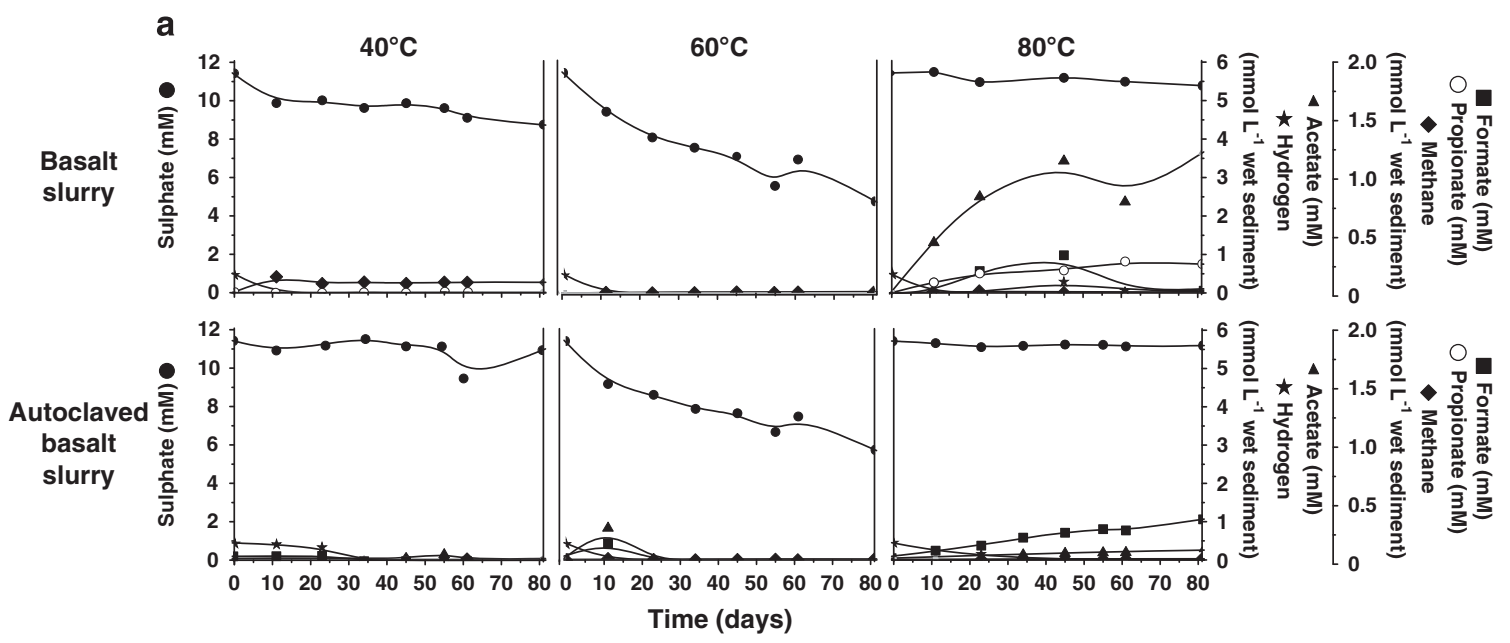

b

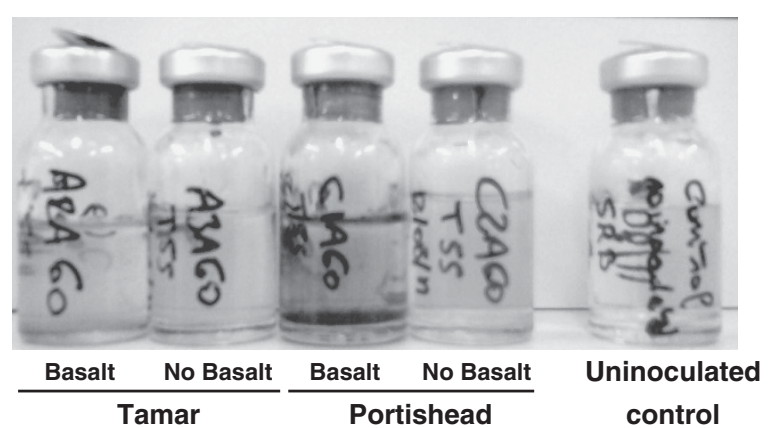

Figure 1 (a) Effect of autoclaving Portishead sediment slurries and incubation at 40, 60 and $80^{\circ} \mathrm{C}$, and (b) subsequent enrichment of autoclaved slurries at $60^{\circ} \mathrm{C}$ along with Tamar Estuary sediment slurries similarly treated. Left to right: A2A60 Tamar slurry with basaltnegative; A3A60 Tamar slurry no basalt-negative; C1A60 Portishead slurry with basalt-positive; C2A60 Portishead slurry without basalt—negative; and uninoculated control—negative.

Table 1 Desulfotomaculum strains used in this study, their cultivation conditions, temperature range and origin

\begin{tabular}{|c|c|c|c|c|c|c|}
\hline \multirow[t]{2}{*}{ Bacterial strain } & \multicolumn{3}{|c|}{ Cultivation conditions } & \multirow{2}{*}{$\begin{array}{l}\text { Temp. } \\
\text { range }\end{array}$} & \multirow[t]{2}{*}{ Origin } & \multirow[t]{2}{*}{ Reference } \\
\hline & Medium & $\begin{array}{l}\text { Growth } \\
\text { Temp. }\end{array}$ & Substrate & & & \\
\hline Desulfotomaculum sp. C1A60 & Marine & $58^{\circ} \mathrm{C}$ & FA mix (2) & $50-72{ }^{\circ} \mathrm{C}$ & Intertidal mudflat & This study \\
\hline D. kuznetsovii DSM $6115^{\mathrm{T}}$ & Fresh & $60^{\circ} \mathrm{C}$ & FA mix (2) & $50-85^{\circ} \mathrm{C}$ & Geothermal water, $3000 \mathrm{mbsf}$ & Nazina et al. (1989) \\
\hline D. geothermicum $\mathrm{B} 2 \mathrm{~T}$ & Marine & $45^{\circ} \mathrm{C}$ & Lactate (20) & $30-65^{\circ} \mathrm{C}$ & Sandstone, $1060 \mathrm{mbsf}$ & Sass and Cypionka (2004) \\
\hline D. thermosapovorans DSM $6562^{\mathrm{T}}$ & Fresh & $45^{\circ} \mathrm{C}$ & Butyrate (10) & $35-60{ }^{\circ} \mathrm{C}$ & Enrichment on rice hulls & Fardeau et al. (1995) \\
\hline Desulfotomaculum sp. NC402 & Fresh & $45^{\circ} \mathrm{C}$ & Lactate (20) & $30-55^{\circ} \mathrm{C}$ & Intertidal mudflat, $50 \mathrm{cmbsf}$ & Sass et al. (2003) \\
\hline D. acetoxidans DSM $771^{\mathrm{T}}$ & Fresh & $25^{\circ} \mathrm{C}$ & Acetate (20) & $20-40^{\circ} \mathrm{C}$ & Piggery waste & Widdel and Pfennig (1977) \\
\hline
\end{tabular}

Abbreviation: FA, fatty acid.

$30 \mathrm{mll}^{-1}$ sodium bicarbonate solution (1 M) from sterile stock solutions. When a visual indication of sulphate reduction by black $\mathrm{FeS}$ formation was required, $0.5 \mathrm{mll}^{-1} \mathrm{FeSO}_{4}\left(1 \mathrm{M}\right.$ in dilute $\mathrm{H}_{2} \mathrm{SO}_{4}$, autoclaved under an $\mathrm{N}_{2}$ atmosphere) was added. Media was reduced by the addition of a few sterile crystals of sodium dithionite, and the $\mathrm{pH}$ adjusted to between 7.2 and 7.4 by addition of sterile $\mathrm{HCl}$ or $\mathrm{Na}_{2} \mathrm{CO}_{3}$, if necessary.

Substrates were added from sterile stocks before inoculation or as a headspace of $\mathrm{H}_{2} / \mathrm{CO}_{2}(80 / 20 \mathrm{vol} / \mathrm{vol})$. The fatty acid mix (FA mix) stock solution contained sodium formate, acetate, propionate, butyrate, valerate and caproate, each at $1 \mathrm{~m}$.

\section{Physiology of Desulfotomaculum sp. C1A60}

Growth and utilization of substrates was tested in dithionite-reduced medium in completely filled screwcap tubes, or in vials or tubes sealed with butyl rubber stoppers with a $\mathrm{H}_{2} / \mathrm{CO}_{2}$ or $\mathrm{N}_{2} / \mathrm{CO}_{2}$ headspace. Positive tests were subcultured to ensure that growth was not due to substrate carry over. Growth of Desulfotomaculum sp. C1A60 at different temperatures was determined in a thermal gradient system (Barnes 
et al., 1998). Three growth substrates were tested: (A) no organic substrates plus $\mathrm{H}_{2} / \mathrm{CO}_{2}$ atmosphere; (B) $2 \mathrm{~mm}$ fatty acid mix plus $\mathrm{H}_{2} / \mathrm{CO}_{2}$ atmosphere; and (C) $2 \mathrm{~mm}$ fatty acid mix plus $\mathrm{N}_{2} / \mathrm{CO}_{2}$ atmosphere. The medium was inoculated with $5 \%$ (vol/vol) of a Desulfotomaculum sp. C1A60 culture that had been grown with $20 \mathrm{~mm}$ sodium lactate and contained no microscopically visible spores or signs of sporulation. In an anaerobic cabinet, $9.5 \mathrm{ml}$ of the appropriate preinoculated medium was aliquoted into sterile glass vials and sealed with butyl rubber septum stoppers. After removal from the cabinet, the vials were crimped and gassed with either $\mathrm{H}_{2} / \mathrm{CO}_{2}$ or $\mathrm{N}_{2} / \mathrm{CO}_{2}$ to a positive pressure. Vials were incubated for 28 days in the thermal gradient system between 16 and $100^{\circ} \mathrm{C}$ and then growth determined by microscopy. Concentrations of sulphate, lactate and fatty acids were determined by ion chromatography (Parkes et al., 2011).

Triple-autoclave experiments with Desulfotomaculum spp

Cultures were assessed microscopically to confirm that they contained spores, and cultures that contained the highest number of spores were selected. However, spore numbers were not standardised for different inoculating cultures and were quite variable. Two different containers were used to detect any potential effect of gas permeability during autoclaving: $15 \mathrm{ml}$ non-gas-tight autoclavable conical plastic tubes (BD Falcon, Oxford, UK) and gas impermeable anaerobic glass tubes with butyl rubber septum stoppers (Bellco, SciQuip, Newtown, UK). In an anaerobic cabinet, $5 \mathrm{ml}$ of culture was aliquoted into tubes, which were then autoclaved in an upright position $\left(121^{\circ} \mathrm{C}\right.$ for $\left.15 \mathrm{~min}\right)$ once, twice or three times. Repeated autoclave runs were started immediately when the autoclave cooled down to $\sim 30^{\circ} \mathrm{C}$ after the previous run. Autoclaved tubes were transferred to an anaerobic cabinet, and $750 \mu \mathrm{l}$ used to inoculate a $50-\mathrm{ml}$ bottle of medium. Replicate bottles were generally screened microscopically after 2 weeks. Negative tubes were further incubated and then re-scored. D. acetoxidans was routinely incubated longer as its growth was slow. Uninoculated media blanks were used as negative controls for each strain. Where pasteurization was carried out it was for $15 \mathrm{~min}$ at $75^{\circ} \mathrm{C}$. Correct autoclave function was confirmed with Merck Sterikon plus Bioindicator autoclaving controls (Merck, Darmstadt, Germany), VWR temperature indicator papers (VWR, Lutterworth, UK, $\pm 1{ }^{\circ} \mathrm{C}$ ) and $3 \mathrm{~m}$ Comply Thermalog Steam Chemical Integrator ( 3 м, Bracknell, UK).

Elevated autoclave and temperature survival experiments

Survival of Desulfotomaculum sp. C1A60 and D. kuznetsovii ${ }^{\mathrm{T}}$ at temperatures above $121^{\circ} \mathrm{C}$ was tested in an autoclave and in an oil bath, for consistent and accurate temperatures (Model ONE 45, Memmert, Schwabach, Germany, temperature stability $\pm 0.3^{\circ} \mathrm{C}$ ).
All cultures were set up in an anaerobic cabinet. For autoclave experiments, $3 \mathrm{ml}$ of inoculum was aliquoted into either a 15-ml Falcon tube or an anaerobic Bellco vial with a butyl rubber septum. After autoclaving, $750 \mu \mathrm{l}$ was used to inoculate a $50-\mathrm{ml}$ bottle of medium. For experiments using the oil bath, $3 \mathrm{ml}$ of the inoculating culture was aliquoted into 30$\mathrm{ml}$ glass serum bottles that were sealed with butyl rubber septum stoppers and crimped. The sealed serum bottles were placed between two fixed metal plates during heating. After heating, either $750 \mu \mathrm{l}$ was removed from the serum bottle with a syringe and used to inoculate a $50-\mathrm{ml}$ bottle of medium, or $15 \mathrm{ml}$ medium was injected directly into the serum bottle.

Desulfotomaculum sp. C1A60 viability of spores and vegetative cells after autoclaving

Vegetative cell-only cultures were grown for about 2 weeks at $58{ }^{\circ} \mathrm{C}$ with $20 \mathrm{~mm}$ lactate as substrate. Microscopic examination showed that the culture contained dividing cells but no spores or evidence of sporulation. The spore-only suspension was prepared by gastrografin density-gradient centrifugation as previously described (Fichtel et al., 2007), and the purified spores were stored in $0.9 \% \mathrm{NaCl}$ at $4{ }^{\circ} \mathrm{C}$ under air, as extended oxygen exposure had previously been found to kill Desulfotomaculum sp. C1A60 vegetative cells. Therefore, any remaining vegetative cells were considered to be non-viable. Microscopic counts of these original untreated suspensions were conducted under coverslips on agar-coated slides. Spore and vegetative cell suspensions were aliquoted $(5 \times 2 \mathrm{ml}$ each) into sterile crimp tubes in the anaerobic cabinet and stored at $4{ }^{\circ} \mathrm{C}$ overnight. The following treatments were then performed: no treatment, pasteurization $(20 \mathrm{~min}$ at $85^{\circ} \mathrm{C}$ in water bath), single, double and triple autoclaving ( $15 \mathrm{~min}$ at $121^{\circ} \mathrm{C}$ each time). Tubes were again stored at $4{ }^{\circ} \mathrm{C}$ overnight before inoculating two parallel most probable number (MPN) series for each treated culture. MPN series were set up in an anaerobic cabinet in 96-deep-well plates (Kopke et al., 2005) using the standard marine dithionitereduced media containing $2 \mathrm{~mm}$ fatty acid mix and $0.5 \mathrm{mM} \mathrm{FeCl}_{2}$. MPN plates were placed in plastic bags containing a catalyst to ensure an anoxic atmosphere and closed using a plastic clip (Anaerocult A mini, VWR). Because of the elevated incubation temperature, $60{ }^{\circ} \mathrm{C}$, the bags were additionally heat-sealed. MPN series were incubated for 17 days. Wells were scored for growth by both visual (black FeS formation) and microscopic examination.

Desulfotomaculum sp. C1A60 16S rRNA and dsrA gene sequences

Genomic DNA was extracted from a Desulfotomaculum sp. C1A60 cell pellet, obtained by centrifugation of a 50-ml culture, using the FastDNA Spin Kit for soil (MP Biomedicals, Santa Ana, CA, USA) and eluted in $100 \mu \mathrm{l}$ molecular biology grade water 
(Severn Biotech Ltd, Kiddeminster, UK). The 16S rRNA and dissimilatory sulphite reductase $(\operatorname{dsr} A B)$ genes were amplified by PCR with primers 27F/ 1492R (Lane, 1991) and DSR1F/DSR4R (Wagner et al., 1998), respectively, using GoTaq Flexi DNA polymerase (Promega Corporation, Southampton, UK) and conditions previously described (Wagner et al., 1998; Webster et al., 2006). The $d s r A B$ PCR product was then purified (QIAquick PCR Purification Kit, Qiagen, Manchester, UK), and sequenced directly with primers DSR1F, DSR4R and DSR3R (Wagner et al., 1998) by Eurofins Genomics (Wolverhampton, UK). However, the 16S rRNA gene could not be sequenced directly because of multiple gene copies. Therefore, triplicate PCR reactions were pooled, purified and concentrated (Amicon Ultra Centrifugal filters; Millipore Ltd, Darmstadt, Germany) before being cloned (pGEM-T Easy Vector System I; Promega Corporation) and transformed into Escherichia coli JM109 competent cells according to the manufacturer's instructions. Colony PCR with transformed cell biomass was then used directly with M13 primers (O’Sullivan et al., 2008) and individual clone 16S rRNA gene products were sequenced (Eurofins Genomics).

All sequence chromatograms were viewed and edited using Chromas Lite software version 2.1.1 (http://www.technelysium.com.au), and 16S rRNA and $d s r A B$ gene consensus sequences were produced from overlapping sequences using BioEdit Sequence Alignment Editor version 7.2.0 (Hall, 1999). Closest sequence matches were identified using the nucleotide blast (blastn) suite at the National Center for Biotechnology Information (NCBI; http://www.ncbi.nlm.nih.gov).

Tyne Estuary sediment slurry 16S rRNA gene sequence and comparative phylogenetic analysis

DNA was extracted from Tyne Estuary sediment slurries using the MoBio PowerSoil DNA Isolation Kit (Cambio Ltd., Cambridge, UK). Extracted DNA was amplified using primers $27 \mathrm{~F} / 1492 \mathrm{R}$ as above and PCR products were cloned using TOPO TA Cloning Kit (Life Technologies Ltd., Paisley, UK) according to the manufacturer's instructions. Clone inserts were amplified with vector primers pUCF (5'-GTTTTCCCAGTCACGAC- $3^{\prime}$ ) and M13R and sequenced (Genevision, Newcastle Upon Tyne, UK). The 16S rRNA gene sequence from the Tyne Estuary sediment slurries, Desulfotomaculum sp. C1A60 clones and other representative Desulfotomaculum spp., including those used in this study, were aligned using ClustalX2 (Larkin et al., 2007), trimmed in BioEdit and phylogenetic trees were constructed using Minimum Evolution and LogDet distance method in MEGA version 6 (Tamura et al., 2013). Congruent trees were also obtained using other methods including neighbour-joining with Jukes-Cantor algorithm, maximum likelihood with the Tamura-Nei model and Maximum Parsimony.
Nucleotide sequence accession numbers

All new nucleotide sequences determined in this study have been deposited in the GenBank database under accession numbers KM065442 to KM065444 for Desulfotomaculum sp. C1A60 16S rRNA genes, KM065445 for Desulfotomaculum sp. C1A60 dsrA gene and KM208880 for the Tyne Estuary sediment slurry bacterium $16 \mathrm{~S}$ rRNA gene.

\section{Results and discussion}

Extremely heat-resistant Desulfotomaculum spores in temperate estuarine sediments

In Portishead non-autoclaved sediment slurries there was no sulphate reduction at $80{ }^{\circ} \mathrm{C}$, despite the formation of volatile fatty acids. However, clear sulphate removal occurred at both 40 and $60{ }^{\circ} \mathrm{C}$, with the rate at $60^{\circ} \mathrm{C}$ being much faster than at $40{ }^{\circ} \mathrm{C}$ (Figure 1). This was surprising as the average seasurface temperature at this location is $\sim 12{ }^{\circ} \mathrm{C}$, with a maximum of $\sim 23^{\circ} \mathrm{C}$, hence, the thermophilic prokaryotes responsible for sulphate reduction at $60{ }^{\circ} \mathrm{C}$ would probably not be active at in situ temperatures. Even more surprising sulphate removal still occurred at $60{ }^{\circ} \mathrm{C}$, even after the slurry was triple autoclaved before incubation (Figure 1). In comparison, no significant sulphate reduction occurred in triple-autoclaved slurries incubated at either 40 or $80^{\circ} \mathrm{C}$. These results were reproducible (data not shown). However, identical experiments with Tamar Estuary sediment slurries also showed sulphate reduction at both 40 and $60{ }^{\circ} \mathrm{C}$, but no activity after autoclaving (unpublished results).

Autoclave-surviving, sulphate-reducing bacteria were also present in sediments from the Tyne Estuary where rapid sulphate removal occurred in $50{ }^{\circ} \mathrm{C}$ sediment slurry incubations previously triple autoclaved (Figure 2). The more rapid sulphate reduction than in Portishead Estuary slurries (Figure 1) presumably was due to the organic substrates added to the Tyne Estuary slurries. However, similar to Portishead sediment incubations no sulphate reduction occurred in slurries incubated at $80^{\circ} \mathrm{C}$. The in situ temperature of the Tyne estuary fluctuates between 4 and $22^{\circ} \mathrm{C}$ annually, so it is again unlikely that these bacteria are active in situ, and hence, they are probably present in these temperate sediments as dormant spores. These and the Tamar Estuary results show that the 1\% Guaymas Basin sediment additional inoculum was probably not the source of the autoclave-surviving, sulphate-reducing bacteria.

\section{Physiology and identity of Desulfotomaculum sp.} C1A60 from autoclaved Portishead Estuary sediments Cultures of Desulfotomaculum sp. C1A60 contained rod-shaped cells, some of which formed central spherical endospores and appeared microscopically pure (Figure 3). Temperature range for growth, based on microscopic cell counts, for $\mathrm{H}_{2} / \mathrm{CO}_{2}$ as a substrate was $50-72^{\circ} \mathrm{C}$, for $2 \mathrm{~mm}$ fatty acid mixture plus 
$\mathrm{H}_{2} / \mathrm{CO}_{2}$ as a substrate was $58-69^{\circ} \mathrm{C}$ and for $2 \mathrm{~mm}$ fatty acid mixture plus $\mathrm{N}_{2} / \mathrm{CO}_{2}$ was $54-69^{\circ} \mathrm{C}$. Similar results were obtained for activity based on sulphate removal or acetate production: $50-72{ }^{\circ} \mathrm{C}, 58-72{ }^{\circ} \mathrm{C}$ and $54-71{ }^{\circ} \mathrm{C}$, respectively. Hence, different substrates have a limited effect on growth and activity temperature range. The minimum and optimum growth temperature of Desulfotomaculum sp. C1A60 is similar to that of D. kuznetsovii ${ }^{\mathrm{T}}$ (minimum $50{ }^{\circ} \mathrm{C}$, optimum $60-65^{\circ} \mathrm{C}$ ), however, the temperature maximum is considerably lower (Table 1). Although Desulfotomaculum sp. C1A60 sporulated well if grown with fatty acids, no spores were observed in cultures with lactate or hydrogen as electron donors. At temperatures above $60^{\circ} \mathrm{C}$, stationary phase cells quickly formed spheroblasts and disintegrated, irrespective of whether sporulation occurred.

Twelve individual 16S rRNA gene clone inserts from Desulfotomaculum sp. C1A60 were fully sequenced, and grouped into three distinct sequence types with variable length. Sequences also contain insertions characteristic of some Desulfotomaculum

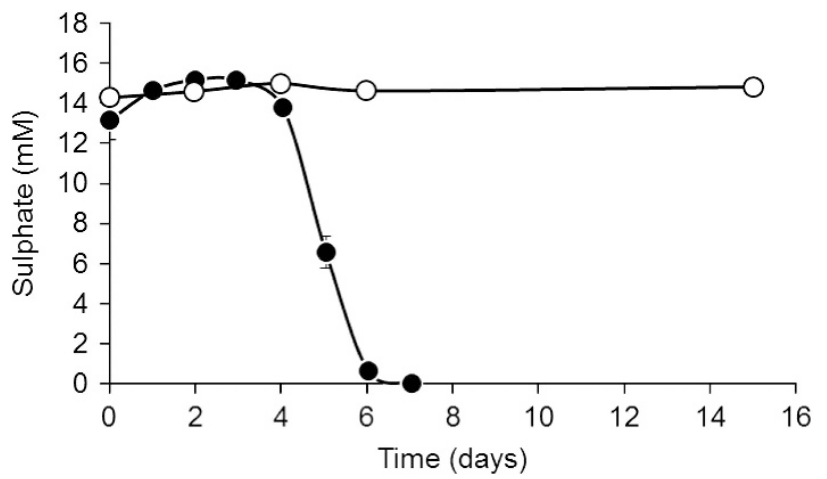

Figure 2 Tyne Estuary sediment slurry incubation following triple autoclaving at $121^{\circ} \mathrm{C}$ for $20 \mathrm{~min}$. Replicate slurries were incubated at $50^{\circ} \mathrm{C}$ (closed symbols) and $80^{\circ} \mathrm{C}$ (open symbols) and the sulphate concentration monitored over a period of 15 days. Slurries were amended with organic substrates ( $3 \mathrm{~mm}$ acetate, propionate, butyrate, lactate, glucose and $3 \mathrm{gl}^{-1}$ tryptic soy broth). No sulphate removal occurred in slurries incubated at $80^{\circ} \mathrm{C}$. Error bars show s.e. $(n=3)$. spp., that have been hypothesised to be involved in the operation of ribosomes at high temperature (Visser et al., 2013), resulting in them being longer than typical 16S rRNA gene sequences: sequence 1 (1695 bp; 7 clone representatives), sequence 2 (1711 bp; 2 clone representatives) and sequence 3 (1676 bp; 3 clone representatives). No other sequences were detected. The three sequence types exhibited between 94\% and 97\% nucleotide sequence similarity to each other, and all exhibited closest sequence similarity to $D$. kuznetsovii DSM $6115^{\mathrm{T}}$ (average $\sim 96 \%$, accession number CP002770), grouping within the Desulfotomaculum subcluster Ic (Stackebrandt et al., 1997, Figure 4). The presence of multiple divergent $16 \mathrm{~S}$ rRNA genes seems to be a characteristic of bacteria related to D. kuznetsovii (Tourova et al., 2001). For example, D. kuznetsovii DSM $6115^{\mathrm{T}}$ (same strain as D. kuznetsovii strain 17) contains at least two divergent 16S rRNA genes (Figure 4). The complete genome sequence of D. kuznetsovii DSM $6115^{\mathrm{T}}$ has shown that in fact it contains three copies of the 16S rRNA gene (Visser et al., 2013): region 1 (1732 bp; 9103-10834 genome sequence location), region 2 (1702 bp; 701879703580 genome sequence location) and region 3 (1697 bp; 2112537-2114233 genome sequence location). The Desulfotomaculum sp. C1A60 dsrA partial nucleotide sequence showed 99\% sequence similarity to the dsrA gene within the genome of D. kuznetsovii DSM 6115 ${ }^{\mathrm{T}}$ (accession number CP002770) and 92-97\% sequence similarity to $d s r A$ genes of thermophilic sulphate-reducing bacteria from an underground heavy-metal mine (Nakagawa et al., 2002). The next closest pure-culture match was with the $d s r A$ gene of $D$. thermocisternum (AF074396) from hot, North Sea oil reservoir water (Nilsen et al., 1996) with 89\% sequence similarity.

\section{Triple-autoclave experiments with Desulfotomaculum spp}

Desulfotomaculum sp. C1A60 grown on $2 \mathrm{~mm}$ fatty acid mix and containing both spores and vegetative cells survived triple autoclaving (Table 2). However,
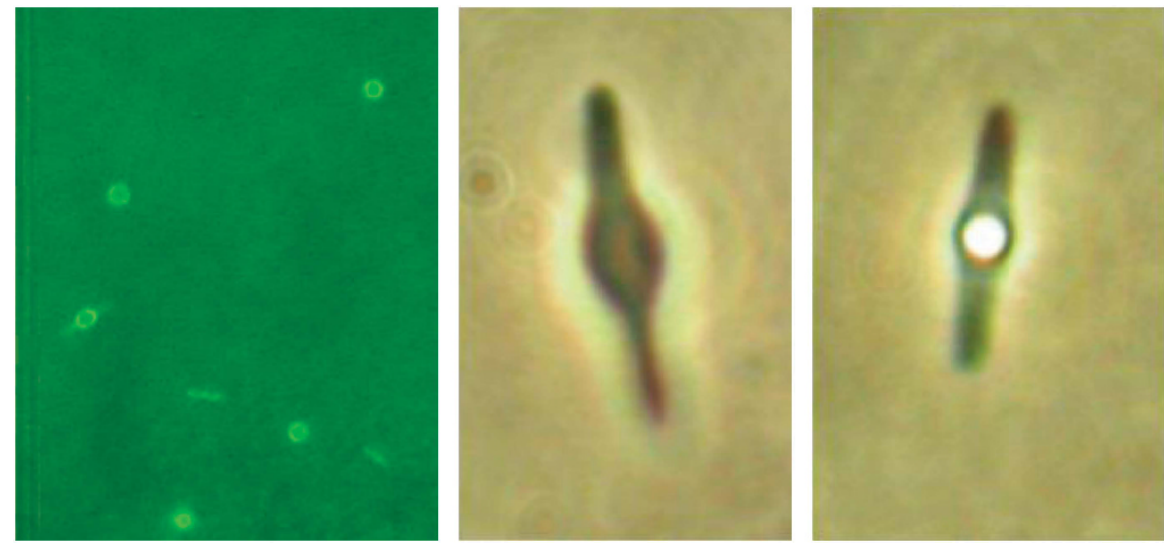

Figure 3 Photomicrographs of Desulfotomaculum sp. C1A60, including a cell with a central endospore. 


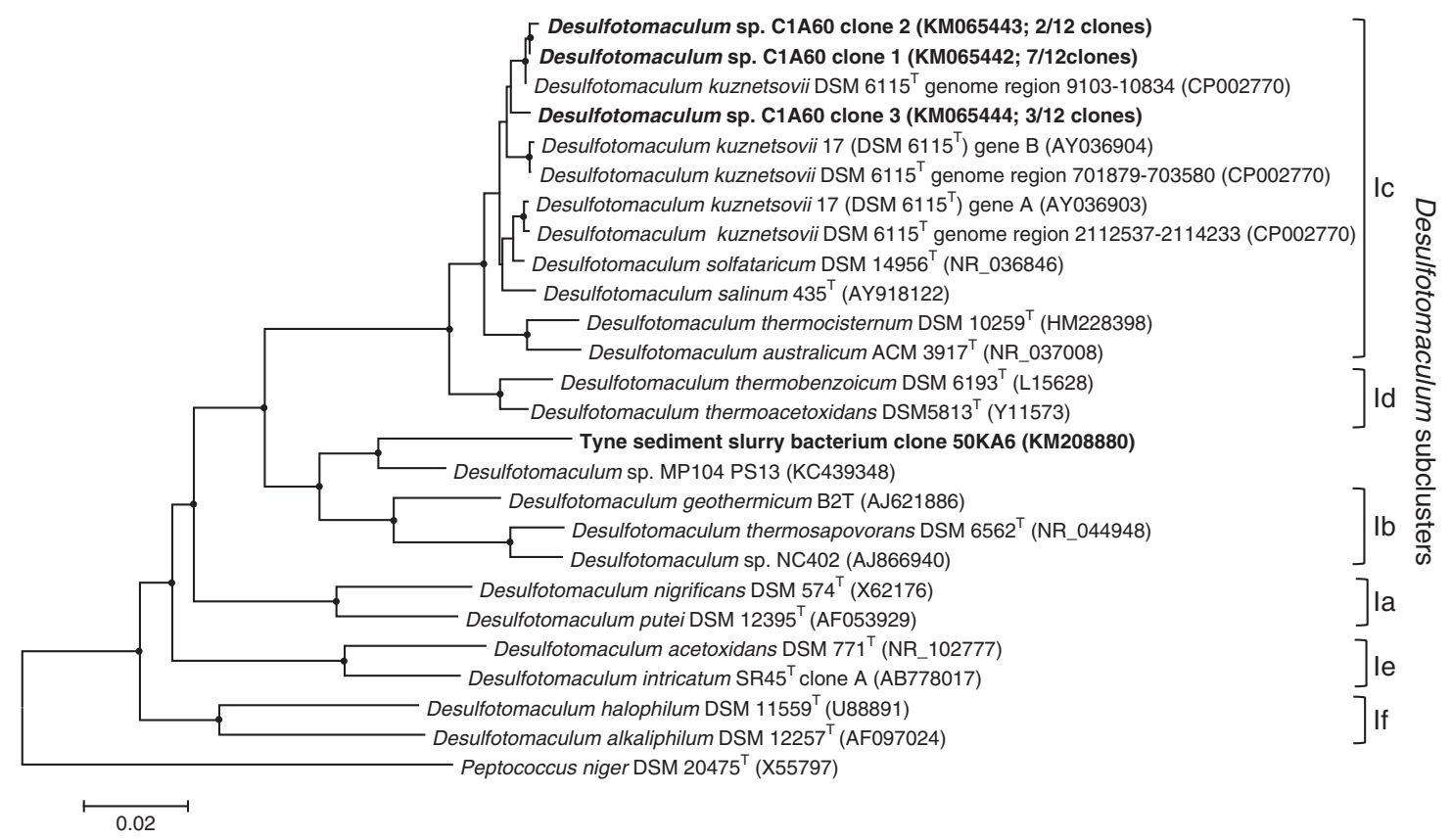

Figure 4 Phylogenetic tree showing the affiliation of the 16S rRNA gene sequences of heat-resistant Desulfotomaculum sp. C1A60 and River Tyne sediment slurry bacterium within the genus Desulfotomaculum. The tree was constructed with 1698 base positions of aligned 16S rRNA gene sequences and obtained using Minimum Evolution and LogDet distance with Peptococcus niger as an outgroup. Bootstrap support values over 50\% (1000 replicates) are indicated by filled circles and bootstrap supported branches were present in all trees calculated using Minimum Evolution with LogDet, as well as neighbour-Joining with Jukes-Cantor and maximum likelihood with Tamura-Nei methods. Scale bar represents $2 \%$ sequence divergence. Desulfotomaculum subclusters are based on those described by Stackebrandt et al. (1997). D. kuznetsovii DSM 6115T and D. kuznetsovii 17 are the same type strain. All new sequences from this study are in bold, with their accession number and the number of clones for each different Desulfotomaculum sp. C1A60 16S rRNA gene given in parentheses.

Desulfotomaculum sp. C1A60 grown on $20 \mathrm{~mm}$ lactate, had only visible vegetative cells and only survived two autoclavings (only limited growth after two autoclavings). It seems likely that survival of autoclaving by lactate-grown cultures was due to a small number spores present in this culture. $D$. kuznetsovii $^{\mathrm{T}}$ (Nazina et al., 1989) and D. geothermicum B2T (Sass and Cypionka, 2004) both originally isolated from geothermal ground waters (Daumas et al., 1988), also survived triple autoclaving. In contrast, D. thermosapovorans, Desulfotomaculum sp. NC402 and D. acetoxidans, did not survive autoclaving. However, they did survive pasteurization, suggesting that the original inoculating cultures did contain some spores. Repeating these autoclaving experiments in gas-tight glass crimp tubes (Bellco) instead of polypropylene Falcon tubes, to prevent any possibility of oxidation during treatment, produced the same results. This indicates that any oxidation of the media during autoclaving in Falcon tubes was not a factor in their subsequent lack of growth. Removal of sulphate and volatile fatty acids in triple-autoclaved cultures of Desulfotomaculum sp. C1A60 (limited acetate produced, $\sim 2.5 \mathrm{~mm}$ ) and D. kuznetsovii ${ }^{\mathrm{T}}$ confirmed activity as well as growth (data not shown). During autoclaving cultures reached a temperature maximum of $132^{\circ} \mathrm{C}$.
High-temperature autoclaving and high-temperature survival experiments

Survival of Desulfotomaculum sp. C1A60 and $D$. kuznetsovii ${ }^{\mathrm{T}}$ cultures was tested under increasingly high autoclave temperatures and times, up to $135^{\circ} \mathrm{C}$ and 15 min (Table 3). Desulfotomaculum sp. C1A60 survived autoclaving at $130^{\circ}$ for $15 \mathrm{~min}$ (both in Falcon and Bellco tubes, maximum temperature reached, $\left.138^{\circ} \mathrm{C}\right)$, but not autoclaving at $135^{\circ} \mathrm{C}(\max$, $154^{\circ} \mathrm{C}$ reached). In contrast, D. kuznetsovii ${ }^{\mathrm{T}}$ cultures survived autoclaving at $135^{\circ} \mathrm{C}$ for $15 \mathrm{~min}$ (max, $154^{\circ} \mathrm{C}$ reached). As this was the upper safety limit of the autoclave, higher temperatures were tested in a heated oil bath, which also provided consistent and more accurate temperatures (Table 4). Consistent with the autoclave results Desulfotomaculum sp. C1A60 survived $15 \mathrm{~min}$ at $130^{\circ} \mathrm{C}$, but in addition, also survived at this temperature for 30 , but not $60 \mathrm{~min}$. D. kuznetsovii ${ }^{\mathrm{T}}$ cultures survived exposure to $140{ }^{\circ} \mathrm{C}$ for $15 \mathrm{~min}$, but not for $30 \mathrm{~min}$ or higher temperatures. Maximum temperatures of the oil bath, which allowed spore survival, were noticeably below the maximum temperatures experienced in the autoclave (Table 3), so length of exposure at maximum temperature may be more crucial than shorter periods at higher temperatures, for spore survival. Interestingly, survival temperatures in the autoclave and non-pressurised oil bath vials were 
Table 2 Effect of pasteurisation and/or repeated autoclaving on survival of Desulfotomaculum sp. CIA60 and related Desulfotomaculum species $(++=$ positive growth, $+=$ limited growth, $--=$ no growth)

\begin{tabular}{|c|c|c|c|c|c|c|}
\hline \multirow[t]{2}{*}{ Test strain } & \multirow[t]{2}{*}{ Autoclave conditions } & \multirow[t]{2}{*}{ Subculture } & \multirow[t]{2}{*}{ Pasteurisation } & \multicolumn{3}{|c|}{ Times autoclaved } \\
\hline & & & & 1 & 2 & 3 \\
\hline $\begin{array}{l}\text { Desulfotomaculum sp. C1A60 (spores and } \\
\text { vegetative cells-grown on } 2 \mathrm{mM} \text { fatty acid mix) }\end{array}$ & Falcon & ++ & & ++ & ++ & ++ \\
\hline $\begin{array}{l}\text { Desulfotomaculum sp. C1A60 (microscopically } \\
\text { vegetative cells only-grown on } 20 \mathrm{mM} \text { sodium lactate) }\end{array}$ & Falcon & ++ & & ++ & + & -- \\
\hline D. kuznetsovii & Falcon & ++ & & ++ & ++ & ++ \\
\hline D. geothermicum B2T & Falcon & ++ & ++ & ++ & ++ & ++ \\
\hline D. thermosapovorans & Falcon & ++ & ++ & -- & -- & -- \\
\hline D. thermosapovorans & Bellco & ++ & ++ & -- & -- & -- \\
\hline Desulfotomaculum sp. NC402 & Falcon & ++ & ++ & -- & -- & -- \\
\hline Desulfotomaculum sp. NC402 & Bellco & + & ++ & -- & -- & -- \\
\hline D. acetoxidans & Falcon & ++ & ++ & -- & -- & -- \\
\hline D. acetoxidans & Bellco & ++ & ++ & -- & -- & -- \\
\hline
\end{tabular}

Falcon tubes are made from autoclavable polypropylene (not gas tight) and Bellco are glass tubes sealed with a septa (anaerobic).

Table 3 Effect of increasing autoclave temperatures and times on the survival of Desulfotomaculum sp. C1A60 and D. kuznetsovii

\begin{tabular}{|c|c|c|c|c|c|}
\hline Test strain & $\begin{array}{l}\text { Autoclave } \\
\text { programmed } \\
\text { temperature }\end{array}$ & $\begin{array}{l}\text { Time } \\
\text { (min) }\end{array}$ & $\begin{array}{l}\text { Autoclave } \\
\text { tubes }\end{array}$ & $\begin{array}{c}\text { Max. temperature } \\
\text { (temperature indicator } \\
\text { papers) }\end{array}$ & $\begin{array}{c}\text { Growth-variable numbers } \\
\text { of replicates positive } \\
\text { subcultures }\end{array}$ \\
\hline \multirow[t]{8}{*}{ Desulfotomaculum sp. C1A60 } & $121^{\circ} \mathrm{C}$ & 15 & Falcon & $132^{\circ} \mathrm{C}$ & ++ \\
\hline & $121^{\circ} \mathrm{C}$ & 30 & Falcon & $132^{\circ} \mathrm{C}$ & ++ \\
\hline & $121^{\circ} \mathrm{C}$ & 60 & Falcon & $132^{\circ} \mathrm{C}$ & ++ \\
\hline & $125^{\circ} \mathrm{C}$ & 15 & Falcon & $138^{\circ} \mathrm{C}$ & ++ \\
\hline & $130^{\circ} \mathrm{C}$ & 15 & Falcon & $138^{\circ} \mathrm{C}$ & ---++ \\
\hline & $130^{\circ} \mathrm{C}$ & 15 & Bellco & $138^{\circ} \mathrm{C}$ & ++ \\
\hline & $135^{\circ} \mathrm{C}$ & 15 & Falcon & $154^{\circ} \mathrm{C}$ & ----- \\
\hline & $135^{\circ} \mathrm{C}$ & 15 & Bellco & $154^{\circ} \mathrm{C}$ & -- \\
\hline \multirow[t]{8}{*}{ D. kuznetsovii } & $121^{\circ} \mathrm{C}$ & 15 & Falcon & $132^{\circ} \mathrm{C}$ & ++ \\
\hline & $121^{\circ} \mathrm{C}$ & 30 & Falcon & $132^{\circ} \mathrm{C}$ & ++ \\
\hline & $121^{\circ} \mathrm{C}$ & 60 & Falcon & $132^{\circ} \mathrm{C}$ & ++ \\
\hline & $125^{\circ} \mathrm{C}$ & 15 & Falcon & $138^{\circ} \mathrm{C}$ & ++ \\
\hline & $130^{\circ} \mathrm{C}$ & 15 & Falcon & $138^{\circ} \mathrm{C}$ & +++++ \\
\hline & $130^{\circ} \mathrm{C}$ & 15 & Bellco & $138^{\circ} \mathrm{C}$ & ++ \\
\hline & $135^{\circ} \mathrm{C}$ & 15 & Falcon & $154^{\circ} \mathrm{C}$ & +++ \\
\hline & $135^{\circ} \mathrm{C}$ & 15 & Bellco & $154^{\circ} \mathrm{C}$ & ++ \\
\hline
\end{tabular}

Number of subcultures that had positive growth $(+)$ or no growth $(-)$. Falcon tubes are made from autoclavable polypropylene (not gas tight) and Bellco are glass tubes sealed with a septa (anaerobic).

not very different, suggesting that pressure on its own is not that important to limiting spore survival, assuming that pressure was higher during autoclaving.

Viability of Desulfotomaculum sp. C1A60 spores and vegetative cells surviving pasteurisation or autoclaving MPN counts of spore-only cultures of Desulfotomaculum sp. C1A60 were progressively reduced with successive autoclavings from 0.596 to 0.061 and $0.023 \%$ recovery (average of two MPN series) for one, two and three autoclavings, respectively (Table 5). In contrast, the MPN counts for the vegetative cell-only culture were markedly reduced by a single autoclaving, and after two and three autoclavings only a few cells survived. It is likely that a small number of spores or spore-containing cells in the vegetative cell culture, not detected microscopically, may have accounted for the limited growth after autoclaving. To account for 93 and 23 cells $\mathrm{ml}^{-1}$ surviving triple autoclaving by considering spore survival, would require $1.53 \times 10^{5}$ and $1.02 \times 10^{5} \mathrm{ml}^{-1}$ spores, respectively, in the original vegetative cell culture. The ability of relatively few spores to grow in culture medium after autoclaving demonstrates the potential significance of even the survival of a small number of spores in the environment to exploit new growth opportunities (for example, using our spore survival data and MPN counts of spore-forming, thermophilic sulphate-reducing bacteria in Portishead sediments (average $2.9 \times 10^{4} \mathrm{~g}^{-1}$ for top $25 \mathrm{~cm}$ of sediment, unpublished results) indicates that only 25 spores may have survived triple autoclaving of slurries, yet sulphate reduction began rapidly, 
Table 4 Survival of Desulfotomaculum sp. C1A60 and D. kuznetsovii cultures at elevated temperature in an oil bath for varying time periods

\begin{tabular}{|c|c|c|c|}
\hline Test strain & Temperature & $\begin{array}{l}\text { Time } \\
\text { (min) }\end{array}$ & $\begin{array}{c}\text { Growth-variable } \\
\text { numbers of replicates } \\
\text { positive subcultures } \\
(+)\end{array}$ \\
\hline \multirow{10}{*}{$\begin{array}{l}\text { Desulfotomaculum } \\
\text { sp. C1A60 }\end{array}$} & $121^{\circ} \mathrm{C}$ & 15 & ++ \\
\hline & $125^{\circ} \mathrm{C}$ & 15 & +++++ \\
\hline & $130^{\circ} \mathrm{C}$ & 15 & ++++ \\
\hline & $130^{\circ} \mathrm{C}$ & 30 & +++ \\
\hline & $130^{\circ} \mathrm{C}$ & 60 & --- \\
\hline & $135^{\circ} \mathrm{C}$ & 15 & ---- \\
\hline & $135^{\circ} \mathrm{C}$ & 30 & --- \\
\hline & $140^{\circ} \mathrm{C}$ & 15 & - \\
\hline & $145^{\circ} \mathrm{C}$ & 15 & -- \\
\hline & $150^{\circ} \mathrm{C}$ & 15 & -- \\
\hline \multirow[t]{11}{*}{ D. kuznetsovii } & $121^{\circ} \mathrm{C}$ & 15 & ++ \\
\hline & $125^{\circ} \mathrm{C}$ & 15 & ++ \\
\hline & $130^{\circ} \mathrm{C}$ & 15 & ++ \\
\hline & $135^{\circ} \mathrm{C}$ & 15 & +++++ \\
\hline & $140^{\circ} \mathrm{C}$ & 15 & +++++ \\
\hline & $140^{\circ} \mathrm{C}$ & 30 & --- \\
\hline & $140^{\circ} \mathrm{C}$ & 60 & --- \\
\hline & $145^{\circ} \mathrm{C}$ & 15 & ----- \\
\hline & $145^{\circ} \mathrm{C}$ & 30 & --- \\
\hline & $145^{\circ} \mathrm{C}$ & 60 & --- \\
\hline & $150^{\circ} \mathrm{C}$ & 15 & -- \\
\hline
\end{tabular}

Figure 1). This is reinforced by the much higher viability of spores, even without treatment compared with vegetative cells $(20 \%$ compared with $0.7 \%$, a factor of $\sim 30$, Table 5 ).

\section{Summary and significance}

The combined high survival and culturability of some Desulfotomaculum spores demonstrated in these experiments could explain why spore-forming bacteria often represent a considerable proportion of culturable diversity in marine sediments (Isaksen et al., 1994), including in Portishead sediments (thermophilic, spore-forming, sulphate-reducing bacteria were $93 \%$ of the total pasteurised plus non-pasteurised MPN thermophilic, sulphate-reducing bacterial counts in the top $25 \mathrm{~cm}$ of sediment, unpublished results). The culturability of Desulfotomaculum spores is $\sim 30$ times greater than that of their vegetative cells (Table 5, comparing direct spore/cell counts with MPN counts). If this reflects the general better culturability of spores compared with vegetative cells, then spore-forming bacteria may be over-represented in culture-based biodiversity surveys. This may be in contrast to their potential under-representation in culture-independent surveys reliant upon extraction of DNA from spores that may be more resistant to lysis than vegetative cells (Wunderlin et al., 2014). The 50-72${ }^{\circ} \mathrm{C}$ growth range of Desulfotomaculum sp. C1A60 means that it cannot grow in situ in Portishead intertidal sediments, which have a maximum temperature of $\sim 23^{\circ} \mathrm{C}$. This situation is the same as observed for Desulfotomaculum sp. C1A60's closest relative $D$. kuznetsovii in other marine sediments (Isaksen et al., 1994) and related types in Tyne Estuary sediments. Despite the thermophilic characteristics of these Desulfotomaculum species, they survive well, presumably as spores, in cold marine sediments, with an estimated half-life of $\sim 300$ years (de Rezende et al., 2013).

In addition, the high temperature and pressure (autoclave) tolerance of some Desulfotomaculum spores would enable them to survive and be dispersed via hot hydrothermal (Dhillon et al., 2003; Wang et al., 2009; Gerasimchuka et al., 2010) crustal (Cowen et al., 2003) and other fluid flow through deep hot sediments, with short exposures to temperatures up to even $140-150{ }^{\circ} \mathrm{C}$ (Tables 3 and 4 and an oil reservoir Desulfotomaculum sp. surviving $131^{\circ} \mathrm{C}$ for $20 \mathrm{~min}$, Rosnes et al., 1991). Hightemperature subsurface environments such as deep petroleum reservoirs could also be inoculated with spore-forming thermophilic Desulfotomaculum spp., (Aullo et al., 2013) via natural fluid flows or for petroleum reservoirs during secondary oil recovery using seawater injection. Consistent with this situation, D. kuznetsovii (Nazina et al., 1989) and D. geothermicum B2T (Sass and Cypionka, 2004), which both survived triple autoclaving, were originally isolated from geothermal ground waters (65 and $58{ }^{\circ} \mathrm{C}$, respectively). Interestingly, $D$. kuznetsovii is the most robust in terms of high-temperature survival and Desulfotomaculum sp. C1A60 from Portishead sediments, which also survives triple autoclaving, is most closely related to this bacterium $(\sim 96 \%)$. In contrast, the thermophilic, autoclavesurviving, sulphate reducer $\left(50^{\circ} \mathrm{C}\right)$ from Tyne estuary sediments (UK), is affiliated to a different Desulfotomaculum subgroup, which contains D. geothermicum (Figure 4). Clearly, for Portishead and probably other sediments, the sediment matrix does not contribute to the triple-autoclave survival of spores, as the Desulfotomaculum sp. C1A60 isolate alone also survives this and higher-temperature treatment (Tables 3 and 4).

Although some hyperthermophiles can survive autoclaving (for example, Pyrolobus fumarii temperature maximum $113^{\circ} \mathrm{C}$, survives 1-h autoclaving at $121{ }^{\circ} \mathrm{C}$ (Blochl et al., 1997), it is surprising that a thermophile, with a much lower temperature maximum $\left(\sim 72^{\circ} \mathrm{C}\right)$, can survive the same and even higher-temperature autoclave conditions (up to $135{ }^{\circ} \mathrm{C}$ for $15 \mathrm{~min}$ autoclaving and $140{ }^{\circ} \mathrm{C}$ for $15 \mathrm{~min}$ in an oil bath-D. kuznetsovii, Tables 3 and 4). However, this extreme high-temperature survival is likely due to spores (Table 5), unlike the archaeon Pyrolobus fumarii, which does not form spores. Other spore-forming bacteria have occasionally been reported to survive autoclaving (Gong et al., 2012), but not sequential double autoclaving (Thomas, 2006), whereas several Desulfotomaculum sp. do not even survive one autoclaving (Table 2). Therefore, the triple-autoclave-surviving 
Table 5 Culturability of Desulfotomaculum sp. C1A60 spores and vegetative cells, surviving pasteurisation or autoclaving based on replicate most probable number (MPN 1 and 2) estimates

\begin{tabular}{lcc}
\hline Treatment & $\begin{array}{c}\text { Spore MPN 1 } \\
\text { spore or cell count ml }{ }^{-1}\end{array}$ & $\begin{array}{c}\text { Spore MPN 2 } \\
\text { spore or cell count ml }\end{array}$ \\
\hline Original spore count & $4.1 \times 10^{6}$ & $4.1 \times 10^{6}$ \\
Untreated MPN count A & $1.1 \times 10^{6}$ & $2.9 \times 10^{4}$ \\
Untreated MPN count B & $1.1 \times 10^{6}$ & $1.1 \times 10^{6}$ \\
Pasteurized & $1.1 \times 10^{6}$ & $1.5 \times 10^{5}$ \\
Single autoclave & $4.6 \times 10^{4}$ & $2.9 \times 10^{3}$ \\
Double autoclave & $4.6 \times 10^{3}$ & $3.9 \times 10^{2}$ \\
Triple autoclave & $1.1 \times 10^{3}$ & $7.5 \times 10^{2}$ \\
Viable spores surviving triple autoclaving & $0.02 \%$ & $0.018 \%$
\end{tabular}

Original cell count

Untreated MPN count A

Untreated MPN count B

Pasteurized

Single autoclave

Double autoclave

Triple autoclave

Viable cells surviving triple autoclaving

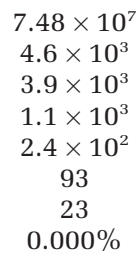

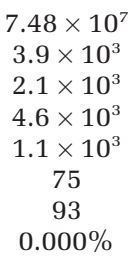

Desulfotomaculum sp. C1A60, D. kuznetsovii, D. geothermicum and the Tyne sediment Desulfotomaculum sp. are rather unusual. Perhaps this is a feature that demonstrates that these thermophilic Desulfotomaculum do experience short exposure to high temperatures in their natural environments or during dispersal, which clearly suggests a hightemperature origin for these Desulfotomaculum spp. and possibly a subsurface origin considering the original source of both D. kuznetsovii and D. geothermicum. Although high-temperature-resistant Desulfotomaculum spp. appear to be common (for example, Portishead and Tyne Estuary sediments and presumably D. kuznetsovii from Aarhus Bay, Isaksen et al., 1994), they are not universally distributed (for example, absent from Tamar Estuary sediments). A similar situation was found in a general survey of endospore-forming, thermophilic Firmicutes (Muller et al., 2014) and differences in distributions were thought to be related to different connectivity of local water masses to ocean circulation.

The unique autoclave and temperature resilience of D. kuznetsovii-related Desulfotomaculum spp. probably reflects a general spore robustness that helps to explain the remarkable survival of some spores on geological timescales (for example, (Cano and Borucki, 1995; Vreeland et al., 2000) and in deep, hot sediments (Parkes et al., 2000, 2014). Research on Bacillus spp. has shown that a major factor determining resistance to wet-heat is the water content of the spore core, with lower core water content generally resulting in greater resistance (Setlow, 2006). During spore germination the core water content is elevated resulting in an increased sensitivity to heat (Setlow, 2014). Other factors contributing to heat resistance include the extent of spore core mineralisation, the sporulation temperature and spore DNA saturation with $\alpha / \beta$-type small, acid-soluble proteins (Nicholson et al., 2000).

The results presented here, may also have relevance to the conditions required for, and bacteria susceptible to, deep-burial sterilization, thought to be responsible for the occurrence of shallow nonbiodegraded, hydrocarbon reservoirs, which are presently at relatively low temperatures (Wilhelms et al., 2001); particularly, the 'sterilizing' temperatures required may be higher for spore-forming bacteria, and some spore-forming bacteria may be particularly rapid re-colonisers. Also, survival after several serial autoclavings provides additional challenges when trying to identify biogenic versus thermogenic processes under high-temperature conditions, and highlights the need to consider longer and higher-temperature autoclaving for effective sterile controls (for example, Parkes et al., 2011; Gong et al., 2012, Tables 2 and 3) and sterility in general (Thomas, 2006).

\section{Conflict of Interest}

The authors declare no conflict of interest.

\section{Acknowledgements}

This research was funded by grants from the Natural Environment Research Council (NE/H021531/1, NE/H02042X/1). Dr Andrew Watkins (Cardiff University) assisted with the agar shake technique and thermal gradient experiments. We acknowledge the helpful reviews of three anonymous referees, which improved the manuscript. 


\section{References}

Aullo T, Ranchou-Peyruse A, Ollivier B, Magot M. (2013). Desulfotomaculum spp. and related Gram-positive sulfate-reducing bacteria in deep subsurface environments. Front Microbiol 4: 362.

Barnes SP, Bradbrook SD, Cragg BA, Marchesi JR, Weightman AJ, Fry JC et al. (1998). Isolation of sulfate-reducing bacteria from deep sediment layers of the Pacific Ocean. Geomicrobiol J 15: 67-83.

Blochl E, Rachel R, Burggraf S, Hafenbradl D, Jannasch HW, Stetter KO. (1997). Pyrolobus fumarii, gen. and sp. nov., represents a novel group of archaea, extending the upper temperature limit for life to 113 degrees C. Extremophiles 1: 14-21.

Cano RJ, Borucki M. (1995). Revival and identification of bacterial spores in 25 to 40 million year old Dominican amber. Science 268: 1060-1064.

Cowen JP, Giovannoni SJ, Kenig F, Johnson HP, Butterfield D, Rappe MS et al. (2003). Fluids from aging ocean crust that support microbial life. Science 299: 120-123.

D'Hondt S, Jorgensen BB, Miller DJ, Batzke A, Blake R, Cragg BA et al. (2004). Distributions of microbial activities in deep subseafloor sediments. Science 306: 2216-2221.

Daumas S, Cordruwisch R, Garcia JL. (1988). Desulfotomaculum geothermicum sp. nov., a thermophilic, fatty acid-degrading, sulfate-reducing bacterium isolated with $\mathrm{H} 2$ from geothermal ground water. Antonie Van Leeuwenhoek 54: 165-178.

de Rezende JR, Kjeldsen KU, Hubert CRJ, Finster K, Loy A, Jorgensen BB. (2013). Dispersal of thermophilic Desulfotomaculum endospores into Baltic Sea sediments over thousands of years. ISME J 7: 72-84.

Dhillon A, Teske A, Dillon J, Stahl DA, Sogin ML. (2003). Molecular characterization of sulfate-reducing bacteria in the Guaymas Basin. Appl Environ Microbiol 69: 2765-2772.

Fardeau ML, Ollivier B, Patel BKC, Dwivedi P, Ragot M, Garcia JL. (1995). Isolation and characterization of a thermophilic sulfate-reducing bacterium, Desulfotomaculum thermosapovorans $\mathrm{sp}$. nov. Int $J$ Syst Bacteriol 45: 218-221.

Fichtel J, Koster J, Rullkotter J, Sass H. (2007). Spore dipicolinic acid contents used for estimating the number of endospores in sediments. FEMS Microbiol Ecol 61: 522-532.

Fichtel J, Koster J, Rullkotter J, Sass H. (2008). High variations in endospore numbers within tidal flat sediments revealed by quantification of dipicolinic acid. Geomicrobiol J 25: 371-380.

Gerasimchuka AL, Shatalovb AA, Novikovb AL, Butorovaa OP, Pimenove NV, Yu. Leind A et al. (2010). The search for sulfate reducing bacteria in mat samples from the lost city hydrothermal field by molecular cloning. Microbiology 79: 96-105.

Ghosh S, Zhang PF, Li YQ, Setlow P. (2009). Superdormant spores of Bacillus Species have elevated wet-heat resistance and temperature requirements for heat activation. J Bacteriol 191: 5584-5591.

Gong X-C, Liu Z-S, Guo P, Chi C-Q, Chen J, Wang X-B et al. (2012). Bacteria in crude oil survived autoclaving and stimulated differentially by exogenous bacteria. PLoS One 7: e40842.

Hall T. (1999). BioEdit: a user-friendly biological sequence alignment editor and analysis program for Windows 95/98/NT. Nucleic Acids Symp Ser 41: 95-98.
Hubert C, Arnosti C, Bruchert V, Loy A, Vandieken V, Jorgensen BB. (2010). Thermophilic anaerobes in Arctic marine sediments induced to mineralize complex organic matter at high temperature. Environ Microbiol 12: 1089-1104.

Hubert C, Loy A, Nickel M, Arnosti C, Baranyi C, Bruchert V et al. (2009). A constant flux of diverse thermophilic bacteria into the cold Arctic seabed. Science 325: 15411544.

Inagaki F, Suzuki M, Takai K, Oida H, Sakamoto T, Aoki K et al. (2003). Microbial communities associated with geological horizons in coastal subseafloor sediments from the Sea of Okhotsk. Appl Environ Microbiol 69: 7224-7235.

Isaksen MF, Bak F, Jørgensen BB. (1994). Thermophilic sulfate-reducing bacteria in cold marine sediments. FEMS Microbiol Ecol 14: 1-8.

Kopke B, Wilms R, Engelen B, Cypionka H, Sass H. (2005). Microbial diversity in coastal subsurface sediments: a cultivation approach using various electron acceptors and substrate gradients. Appl Environ Microbiol 71: 7819-7830.

Lane DJ. (1991). 16S/23S rRNA sequencing. In: Stackebrandt E, Goodfellow M, Eds Nucleic Acid Techniques in Bacterial Systematics. John Wiley and Sons: New York, NY, USA, pp 115-175.

Larkin MA, Blackshields G, Brown NP, Chenna R, McGettigan PA, McWilliam H et al. (2007). Clustal W and clustal X version 2.0. Bioinformatics 23: 2947-2948.

Lomstein BA, Langerhuus AT, D’Hondt S, Jorgensen BB, Spivack AJ. (2012). Endospore abundance, microbial growth and necromass turnover in deep sub-seafloor sediment. Nature 484: 101-104.

Muller AL, de Rezende JR, Hubert CRJ, Kjeldsen KU, Lagkouvardos I, Berry D et al. (2014). Endospores of thermophilic bacteria as tracers of microbial dispersal by ocean currents. ISME J 8: 1153-1165.

Nakagawa T, Hanada S, Maruyama A, Marumo K, Urabe T, Fukui M. (2002). Distribution and diversity of thermophilic sulfate-reducing bacteria within a $\mathrm{Cu}-\mathrm{Pb}-\mathrm{Zn}$ mine (Toyoha, Japan). FEMS Microbiol Ecol 41: 199-209.

Nazina TN, Ivanova AE, Kanchaveli LP, Rozanova EP. (1989). A new sporeforming thermophilic methylotrophic sulfate-reducing bacterium, Desulfotomaculum kutznetsovii sp. nov. Mikrobiologiya (Translated) 57: 823-827.

Nicholson WL, Munakata N, Horneck G, Melosh HJ, Setlow P. (2000). Resistance of Bacillus endospores to extreme terrestrial and extraterrestrial environments. Microbiol Mol Biol Rev 64: 548-572.

Nilsen RK, Torsvik T, Lien T. (1996). Desulfotomaculum thermocisternum sp nov, a sulfate reducer isolated from a hot North Sea oil reservoir. Int J Syst Bacteriol 46: 397-402.

O’Sullivan LA, Webster G, Fry JC, Parkes RJ, Weightman AJ. (2008). Modified linker-PCR primers facilitate complete sequencing of DGGE DNA fragments. J Microbiol Methods 75: 579-581.

Parkes R, Linnane C, Webster G, Sass H, Weightman A, Hornibrook E et al. (2011). Prokaryotes stimulate mineral H2 formation for the deep biosphere and subsequent thermogenic activity. Geology 39: 219-222.

Parkes RJ, Cragg B, Roussel E, Webster G, Weightman A, Sass H. (2014). A review of prokaryotic populations and processes in sub-seafloor sediments, including biosphere:geosphere interactions. Mar Geol 352: 409-425. 
Parkes RJ, Cragg BA, Wellsbury P. (2000). Recent studies on bacterial populations and processes in subseafloor sediments: a review. Hydrogeol J 8: 11-28.

Parkes RJ, Sass H, Webster G, Watkins AJ, Weightman AJ, O'Sullivan LA et al. (2009). Methods for studying methanogens and methanogenesis in marine sediments. In Timmis Kenneth N.) (ed. Handbook of Hydrocarbon and Lipid Microbiology. Springer: Berlin, Germany, Part 33 Chapter 36 3801-3826.

Reineke K, Mathys A, Heinz V, Knorr D. (2013). Mechanisms of endospore inactivation under high pressure. Trends Microbiol 21: 296-304.

Rosnes JT, Torsvik T, Lein T. (1991). Spore-forming thermophilic sulfate-reducing bacteria isolated from North Sea oil field waters. Appl Environ Microbiol 57: 2302-2307.

Sass H, Cypionka H. (2004). Isolation of sulfate-reducing bacteria from the terrestrial deep subsurface and description of Desulfovibrio cavernae sp nov. Syst Appl Microbiol 27: 541-548.

Sass H, Rütters H, Schledjewski R, Freese E. (2003). The influence of seasonal changes on microbial communities in the Wadden Sea. Berichte Forschungszentrum Terramare 12: 99-102.

Setlow P. (2006). Spores of Bacillus subtilis: their resistance to and killing by radiation, heat and chemicals. J Appl Microbiol 101: 514-525.

Setlow P. (2014). Germination of spores of Bacillus species: what we know and do not know. J Bacteriol 196: 1297-1305.

Stackebrandt E, Sproer C, Rainey FA, Burghardt J, Pauker O, Hippe H. (1997). Phylogenetic analysis of the genus Desulfotomaculum: evidence for the misclassification of Desulfotomaculum guttoideum and description of Desulfotomaculum orientis as Desulfosporosinus orientis gen. nov., comb. nov. Int J Syst Bacteriol 47: 1134-1139.

Suss J, Engelen B, Cypionka H, Sass H. (2004). Quantitative analysis of bacterial communities from Mediterranean sapropels based on cultivation-dependent methods. FEMS Microbiol Ecol 51: 109-121.

Tamura K, Stecher G, Peterson D, Filipski A, Kumar S. (2013). MEGA6: molecular evolutionary genetics analysis version 6.0. Mol Biol Evol 30: 2725-2729.

Thomas P. (2006). Reemergence of covert bacteria Bacillus pumilus and Brevibacillus sp in microbe-freed grape and watermelon stocks attributable to occasional autoclaving-defying residual spores from previous cycles. Plant Cell Tiss Organ Cult 87: 155-165.

Tourova TP, Kuznetzov BB, Novikova EV, Poltaraus AB, Nazina TN. (2001). Heterogeneity of the nucleotide sequences of the 16S rRNA genes of the type strain of Desulfotomaculum kuznetsovii. Microbiology 70: 678-684.

Visser M, Worm P, Muyzer G, Pereira IAC, Schaap PJ, Plugge CM et al. (2013). Genome analysis of Desulfotomaculum kuznetsovii strain 17(T) reveals a physiological similarity with Pelotomaculum thermopropionicum strain SIT. Stand Genomic Sci 8: 69-87.

Vreeland RH, Rosenzweig WD, Powers DW. (2000). Isolation of a 250 million-year-old halotolerant bacterium from a primary salt crystal. Nature 407: 897-900.

Wagner M, Roger AJ, Flax JL, Brusseau GA, Stahl DA. (1998). Phylogeny of dissimilatory sulfite reductases supports an early origin of sulfate respiration. J Bacteriol 180: 2975-2982.

Wang F, Zhou H, Meng J, Peng X, Jiang L, Sun P et al. (2009). GeoChip-based analysis of metabolic diversity of microbial communities at the Juan de Fuca Ridge hydrothermal vent. Proc Natl Acad Sci USA 106: 4840-4845.

Webster G, Parkes RJ, Cragg BA, Newberry CJ, Weightman AJ, Fry JC. (2006). Prokaryotic community composition and biogeochemical processes in deep subseafloor sediments from the Peru Margin. FEMS Microbiol Ecol 58: $65-85$.

Wellsbury P, Herbert RA, Parkes RJ. (1994). Bacterial [methyl-H-3]thymidine incorporation in substrateamended estuarine sediment slurries. FEMS Microbiol Ecol 15: 237-248.

Widdel F, Bak F. (1992). Gram-Negative Mesophilic Sulfate-Reducing Bacteria. The Prokaryotes(eds Starr MP, Stolp H, Truper HG, Balows A, Schlegal. HG2nd edn vol. 1. Springer: Berlin, Germany 3352-3378.

Widdel F, Pfennig N. (1977). A new anaerobic, sporing, acetate-oxidizing, sulfate-reducing bacterium, Desulfotomaculum (emend.) acetoxidans. Arch Microbiol 112: 119-122.

Wilhelms A, Larter SR, Head I, Farrimond P, di-Primio R, Zwach C. (2001). Biodegradation of oil in uplifted basins prevented by deep- burial sterilization. Nature 411: 1034-1037.

Wolin EA, Wolin MJ, Wolfe RS. (1963). Formation of Methane by Bacterial Extracts. J Biol Chem 238: 2882-2886.

Wunderlin T, Junier T, Roussel-Delif L, Jeanneret N, Junier P. (2014). Endospore-enriched sequencing approach reveals unprecedented diversity of Firmicutes in sediments. Environ Microbiol Rep; doi:10.1111/17582229.1279 .

This work is licensed under a Creative Commons Attribution 3.0 Unported License. The images or other third party material in this article are included in the article's Creative Commons license, unless indicated otherwise in the credit line; if the material is not included under the Creative Commons license, users will need to obtain permission from the license holder to reproduce the material. To view a copy of this license, visit http:// creativecommons.org/licenses/by/3.0/ 